\title{
Global Law as Inter-contextuality and as Inter-legality
}

\author{
Poul F. Kjaer
}

This is the final authors' version. The final version is published in Jan Klabbers and Gianluigi Palombella (eds.): The Challenge of Inter-legality (Cambridge: Cambridge University Press, 2019), pp. $302-318$.

1. Introduction

Since the 1990s the effects of globalization on law and legal developments has been a central topic of scholarly debate. ${ }^{1}$ To date, the debate is however marked by three substantial deficiencies which this chapter seeks to remedy through a reconceptualization of global law as a law of intercontextuality expressed through inter-legality and materialized through a particular body of legal norms which can be characterized as connectivity norms.

The first deficiency is a historical and empirical one. Both critics as well as advocates of 'non-state law' share the assumption that 'law beyond the state' and related legal norms have gained in

\footnotetext{
${ }^{1}$ See, e.g., M. Shapiro, 'The Globalization of Law', (1993) 1 Indiana Journal of Global Legal Studies 37.
} 
centrality when compared with previous historical times. ${ }^{2}$ While global law, including both public and private global governance law as well as regional occurrences such as EU law, has undergone profound transformations since the structural transformations which followed the decolonialization processes of the mid-twentieth century, we do not have more global law relatively to other types of law today than in previous historical times.

The second deficiency is a methodological one. The vast majority of scholarship on global law is either of an analytical nature, drawing on insights from philosophy ${ }^{3}$, or empirically observing the existence of global law and the degree of compliance with global legal norms at a given moment in time. $^{4}$ While both approaches bring something to the table they remain static approaches incapable of explaining and evaluating the transformation of global law over time. ${ }^{5}$

The third deficiency is a conceptual-theoretical one. In most instances, global law is understood as a unitary law producing singular legal norms with a planetary reach, ${ }^{6}$ or, alternatively, a radical

\footnotetext{
${ }^{2}$ For the critics, see e.g. D. Grimm, Constitutionalism: Past, Present, and Future (Oxford University Press, 2016); M. Loughlin, 'The Misconceived Search for Global Law', (2017) 8 Transnational Legal Theory 353. For the advocates, see e.g. P.S. Berman, Global Legal Pluralism: A Jurisprudence of Law Beyond Borders (Cambridge University Press, 2012); G. Teubner, 'Global Bukowina: Legal Pluralism in the World Society', in G. Teubner (ed.), Global Law Without a State (Brookfield: Dartmouth, 1997) 3.

${ }^{3}$ See, e.g., T. Pogge, 'Fighting Global Poverty', (2017) 13 International Journal of Law in Context 512.

${ }^{4}$ See, e.g., G. Shaffer and T. Ginsburg, 'The Empirical Turn in International Legal Scholarship', (2012) 106 American Journal of International Law 1; M. Zürn, 'Introduction: Law and Compliance at Different Levels', in M. Zürn and C. Joerges (eds.), Law and Governance in Postnational Europe: Compliance Beyond the Nation-State (Cambridge University Press, 2005) 1.

${ }^{5}$ H. Brunkhorst, Critical Theory of Legal Revolutions: Evolutionary Perspectives (London: Bloomsbury, 2014).

${ }^{6}$ See, e.g., J. Habermas, 'The Constitutionalization of International Law and the Legitimation Problems of a Constitution for World Society', (2008) 15 Constellations 444.
} 
pluralist perspective is adopted dismissing the existence of singular global norms. ${ }^{7}$ Both of these approaches however misapprehend the structural characteristics, function and societal effects of global law. Instead a third positon between unitary and radical pluralist perspectives can be adopted through an understanding of global law and its related legal norms as a de-centred kind of inter-contextual law characterised by inter-legality. ${ }^{8}$

Global law can be defined as a legal phenomenon which, in principle, is unlimited in reach, i.e. as claiming validity without reference or limitation to a specific territory or population, albeit for practical reasons, it will be limited in most cases. ${ }^{9}$ This makes global law distinct from national, international, transnational and community-based living law as defined in the following manner: national law, the law of nation states as derived from the concept of sovereignty; international law, the law between nation states; transnational law, any law which, in terms of jurisdiction,

\footnotetext{
${ }^{7}$ N. Krisch, Beyond Constitutionalism: The Pluralist Structure of Postnational Law (Oxford University Press, 2010).

${ }^{8}$ M. Amstutz and V. Karavas, 'Weltrecht: Ein Derridasches Monster', in: G-P. Calliess, A. Fischer-Lescano, D. Wielsch and P. Zumbansen (eds.), Soziologische Jurisprudenz. Festschrift für Gunther Teubner zum 65. Geburtstag (Berlin: Walter de Gruyter, 2009) 645; T. Duve, 'Was ist 'Multinormativität'? - Einführende Bemerkungen', (2017) 25 Rechtsgeschichte - Legal History 88.

${ }^{9}$ S. Cassese, Il diritto globale. Giustizia e democrazia oltre lo Stato (Turin: Einaudi, 2009); B. Frydman, 'Comment penser le droit global?', in J-Y. Chérot and B. Frydman (eds.). La Science du droit dans la globalisation (Brussels: Bruylant, 2012), 17; P. Le Golf, 'Global Law: A Legal Phenomenon Emerging from the Process of Globalization', (2007) 14 Indiana Journal of Global Legal Studies 119; G. Lhuilier, Le Droit Transnational (Paris: Dalloz, 2016); H. Lindahl, Fault Lines of Globalization: Legal Order and the Politics of A-Legality (Oxford University Press, 2013); G. Palombella, $\grave{E}$ possibile una legalità globale? II Rule of law e la governance del mondo (Bologna: II Mulino, 2012), G. Palombella, 'Global Law and the Law on the Globe', (2012) 4 Italian Journal of Public Law 53; N. Walker, Intimations of Global Law (Cambridge University Press, 2015); M. Xifaras, 'The Global Turn in Legal Theory', (2016) 29 Canadian Journal of Law and Jurisprudence 215.
} 
source or effect, crosses national boundaries thereby producing negative or positive externalities while continuing to rely on national legal sources and instruments; ${ }^{10}$ living law, social norms fulfilling law like functions within a community. ${ }^{11}$ These four types of law might therefore potentially act as sources of inter-legal global law to the extent that they are deployed in an intercontextual manner.

Reflecting its inter-legal structure, the substantial normative content of global law is furthermore characterized by a relative structural predominance of connectivity norms. Connectivity norms are oriented towards the facilitation of transplantations, i.e. the extraction, transmission and incorporation of components of meaning, from one legally structured context to another as, for example, is the case within international trade and investment law, internal market law or legally sanctioned missionary activities within religious law. ${ }^{12}$ The concept of connectivity norms thereby differs from the classical understanding of norms as coherency norms, aimed at establishing coherency within a collectivity on the basis of prescriptions of actions which limit the scope of possible future actions and the invoking of sanctions in the case of non-compliance. ${ }^{13}$ It also

\footnotetext{
${ }^{10}$ Ph.C. Jessup, Transnational Law (New Haven CT: Yale University Press, 1956); Walker, Intimations of Global Law; G-
} P. Calliess and P. Zumbansen, Rough Consensus and Running Code: A Theory of Transnational Private Law (Oxford: Hart Publishing, 2010).

${ }^{11}$ R. Cotterrell, Living Law: Studies in Legal and Social Theory (Farnham: Ashgate Publishing, 2008); E. Ehrlich, Grundlegung der Soziologie des Rechts, $4^{\text {th }}$ edn. (Berlin: Duncker \& Humblot, 1989 ([1913]).

${ }^{12}$ E.g. for trade law see D. Trubek and P. Cottrell, 'Robert Hudec and the Theory of International Economic Law: The Law of Global Space in Developing Countries' in C. Thomas and J. Trachtman (eds.), Developing Countries in the WTO Legal System (Oxford University Press, 2009) 129.

${ }^{13}$ E.g. J. Blake and D. Kingsley, 'Norms, Values, and Sanctions', in R. Faris (ed.), Handbook of Modern Sociology (Chicago II: Rand-McNally, 1964) 456; H.J. Morgenthau, La réalité des normes: En particulier normes du droit international. Fondement d'une théorie des norms (Paris: Félix Alcan, 1934); T. Parsons, The Structure of Social Action: 
differs from a progressive understanding of norms as possibility norms, implying the articulation of possible futures on the basis of a distinction between the factual and the contra-factual, i.e. through a distance to the factual world, with the objective of accentuating the openness of the future. ${ }^{14}$ Connectivity norms are, in other words, a third type of norms located in-between coherency and possibility norms.

\section{The Historicity of Global Law}

Global law can also be understood as boundary-less or universalizing law historically manifested in imperial and religious, e.g. Christian, Jewish and Islamic, law. The duality of imperial and religious law not only preceded nation-state and international law but also remained the dominant form of law until recent historical times. For religious law, the ongoing clashes between secularised 'western law' and Islamic law and the Holy See's continued insistence on formal supremacy vis-àvis all worldly and temporal powers testifies that this battle is not over yet. ${ }^{15}$ The globality of imperial law was manifested in its claim to universal supremacy or a primus inter pares position vis-à-vis all other worldly powers as, for example, found in both Roman law and in the legal conceptuality of Chinese, Japanese and Persian imperial law until the twentieth century. Classical

A Study in Social Theory with Special Reference to a Group of Recent European Writers (New York: Free Press, 1968 [1937]).

${ }^{14}$ R.M. Cover, 'The Supreme Court 1982 Term Foreword: Nomos and Narrative', (1983) 97 Harvard Law Review 4; N. Luhmann, Rechtssystem und Rechtsdogmatik (Stuttgart: Kohlhammer, 1974); C. Möllers, Die Möglichkeit der Normen. Über eine Praxis jenseits von Moralität und Kausalität (Berlin: Suhrkamp Verlag, 2015).

${ }^{15}$ P.F. Kjaer, 'Claim-making and Parallel Universes: The Legal Pluralism of Church, State and Empire in Europe', in G. Davies and M. Avbelj (eds.) Handbook on EU Legal Pluralism (Cheltenham, Edward Elgar Publishing, 2018$) 11$. 
imperial law was based on a built-in asymmetry in favour of the imperial power vis-à-vis other powers, as for example expressed through the Chinese tributary system formally only acknowledging other states as tributary states as well as through the concept of suzerain, i.e. upper-sovereign, originally used to describe the asymmetric relations between the Ottoman Empire and surrounding powers. ${ }^{16}$ In the European context, imperial law remained the paradigmatic form of law until the implosion of the Austria-Hungarian, German, Ottoman and Russian empires in $1917 / 18$, as all of the European empires formally claimed, albeit the claim was increasingly diluted as time progressed, successor status to either the West or East Roman Empires and thereby a transcendent status as universal powers.

From the late fifteenth century until the mid-twentieth century social processes with a factual global reach were however predominantly structured through the colonial variant of imperial law. Colonial law is a specific sub-species of law with particular characteristics. This does not infer an understanding of colonial law as a unified law with a coherent doctrinal basis. Colonial law is, instead, to be conceived of as a collage of partly overlapping and partly contradictory legal principles and practices derived from a range of jurisdictions and sources producing a variety of different effects. ${ }^{17}$

In its various forms colonial law however shares three overarching characteristics:

\footnotetext{
${ }^{16}$ For China see Song Nianshen, "Tributary' from a Multilateral and Multilayered Perspective', (2012) 5 Chinese Journal of International Politics 155.

${ }^{17}$ A. Fitzmaurice, Sovereignty, Property and Empire, 1500-2000 (Cambridge University Press, 2014); O. Grandmaison, 'The Exception and the Rule: On French Colonial Law', (2006) 53 Diogenes 34; M. Koskenniemi, 'Colonial Laws: Sources, Strategies and Lessons?', (2016) 18 Journal of the History of International Law 248; J. Osterhammel, Colonialism: A Theoretical Overview, 2nd ed. (Princeton NJ: Princeton University Press, 2005).
} 
Globality: A common denominator of colonial law is that it can be deployed in a non-specified number of geographical locations, thereby gaining a specific non-territorial trait. This is, for example, expressed in the concept of terra nullius and legal principles concerning the right to exploration, passage and settlement.

Asymmetry: Just as classical imperial law was based on a built-in bias in favour of the imperial power vis-à-vis other powers, the norms of colonial law are derived from asymmetric distinctions, such as Christians/non-Christians and civilised/non-civilised, thereby allowing for the use of 'unequal treaties' between colonial powers and legal entities subject to colonialization or colonial interference. $^{18}$

A materiality/norm nexus: Colonial law implied a two-way street between the legal facilitation of the extraction of values of a predominantly economic nature and the imposition of values and social praxes of a principally religious and moral nature, as, for example, expressed through missionary and civilising activities.

In practice, colonial law thereby came to act as hybrid law structuring relations between different European legal orders and the rest of the world. This is reflected in a tension between the existence of singular ius publicum europaeum and the anchoring of colonial law within different European, i.e. Belgian, British, Danish, Dutch, French, German, Italian, Portuguese, Russian and Spanish, legal orders. ${ }^{19}$ More fundamentally, it is reflected in the way colonial law, based on a fundamental asymmetry in favour of the colonial powers, establishes material interconnectedness through its location in-between the (inter-)national legal orders of the colonial powers and local

\footnotetext{
${ }^{18}$ For China see, for example, Dong Wang, 'The Discourse of Unequal Treaties in Modern China', (2003) 76 Pacific Affairs 399.

${ }^{19}$ C. Schmitt, Der Nomos der Erde. Im Völkerrecht des Jus Publicum Europaeum (Berlin: Duncker \& Humblot, 1950).
} 
(pre-existing) legal orders and the customary living law of societies subject to colonialization. ${ }^{20}$ Colonial law can thereby be understood as a law of in-betweenness and inter-contextuality or as an 'in-between world's law'. ${ }^{21} \mathrm{~A}$ type of in-betweenness which furthermore served a constitutive function in so far as both the legal conglomerate of rather diverse elements making up the ius publicum europaeum and the living law of colonised societies were constituted in this process. Rather than being 'pure', 'natural' or 'indigenous', the living law of colonial society often emerged in the meeting with Europeans as a part of a strategy aimed at handling the intrusion, ${ }^{22}$ just as the constitutive distinction of the ius publicum europaeum was the distinction between Europeans and non-Europeans. Meeting within the form of asymmetric colonial law it was, in other words, the relational interaction embedded in material interconnectedness between colonisers and the colonised which constituted both. Colonial law took the form of assemblages combining elements from focal social processes, i.e. economic and religious processes, from indigenous law and social practices as well as from the legal and social orders of the colonising powers effectively creating a third space characterised by norms of connectivity and inter-connectedness which was neither part of the world of colonisers or the colonised.

\section{Global Governance Law as Post-Imperial Law}

\footnotetext{
${ }^{20}$ M. Chanock, Law, Custom, and Social Order: The Colonial Experience in Malawi and Zambia (Cambridge University Press, 1985).

${ }^{21}$ M. Amstutz, 'In-Between Worlds: Marleasing and the Emergence of Interlegality in Legal Reasoning', (2005) 11 European Law Journal 766.

${ }^{22}$ L. Benton, Law and Colonial Cultures: Legal Regimes in World History, 1400-1900 (Cambridge University Press, 2002); S.E. Merry, 'From Law and Colonialism to Law and Globalization', (2003) 28 Law and Social Inquiry 569.
} 
Today only few remnants of colonialism exist with the United Nations currently listing 17 territories as having colonial status. ${ }^{23}$ The structural transformation brought about by decolonization and the concordant breakdown of the euro-centric world is however still not sufficiently understood with the actual effects of this transformation only starting to become visible with the ongoing breakdown of the Western-centric, i.e. United States-centric, world which succeeded the euro-centric world. ${ }^{24}$ Decolonization, however, implied a dual and simultaneous structural transformation of legal ordering. First, a globalization of statehood through the massive multiplication of the number of states in the wake of decolonization thereby indicating that the widespread narrative concerning the withering away of the state is empirically unfounded. On the contrary, since 1945 the largest expansion of statehood to date has occurred. Until the midtwentieth century statehood remained a limited phenomenon and it is only in very recent historical times that statehood became globalized. Secondly, the restructuring of global law from centre/periphery based asymmetric colonial law to the type of functional regimes, or, as is the case with the EU, conglomerates of functional regimes, which is the central characteristic of contemporary global governance. ${ }^{25}$ Statehood and extensive forms of global law are therefore not structured in a zero-sum relation where more of one implies less of the other. On the contrary, they are mutually constitutive with more of one implying more of the other. The formation and

\footnotetext{
${ }^{23}$ http://www.un.org/en/decolonization/nonselfgovterritories.shtml (accessed 14 March 2018).

${ }^{24}$ P.F. Kjaer, Constitutionalism in the Global Realm - A Sociological Approach (Abingdon: Routledge, 2014).

${ }^{25}$ A. Fischer-Lescano and G. Teubner, 'Regime-Collisions: The Vain Search for Legal Unity in the Fragmentation of Global Law', (2004) 25 Michigan Journal of International Law 999; A. Fischer-Lescano and G. Teubner, RegimeKollisionen: Zur Fragmentierung des globalen Rechts (Frankfurt am Main: Suhrkamp Verlag, 2006); M. Koskenniemi and P. Leino, 'Fragmentation of International Law? Postmodern Anxieties', (2002) 15 Leiden Journal of International Law 553-9. For the EU, see P.F. Kjaer, Between Governing and Governance: On the Emergence, Function and Form of Europe's Post-national Constellation (Oxford: Hart Publishing, 2010).
} 
consolidation of modern territorial states in Western Europe was closely linked to the emergence of increasingly vast colonial empires and vice versa. The progressive transformation of territorial states into nation states was in similar vein intimately linked to the emergence of contemporary global governance. From the establishment of the first modern public international organisation La Commission centrale pour la navigation du Rhin, initiated at the Congress of Vienna in 1815 , to the explosion in the number of global governance sites in the latter half of the twentieth century, the evolution of modern global governance has gone hand in hand with the concordant expansion and deepening of statehood. ${ }^{26}$

The law of the continental empires of Eurasia, stretching from Europe to China, and the colonial empires hinged on the western-most European states had considerable differences in their legal structuring while in principle sharing a boundary-less and asymmetric approach to the world. In a similar vein contemporary global governance law comes in two species: a predominantly private law, i.e. contract law, based structuring of global connectivity mainly oriented towards economic exchanges, and a public law structuring of, in principle, boundary-less, political power, as particularly manifested in EU law. The relationship between the pre-existing imperial legal formations and contemporary global governance is at the same time one of perfect continuity and fundamental discontinuity. Just like modern territorially delineated European nation states emerged from within pre-existing feudal forms of legal ordering while still obtaining a fundamental different form and normative outlook, both species of contemporary global governance emerged from within the pre-existing imperial forms, while being substantially transformed in the process of emergence leading to a reliance on different organizational

\footnotetext{
${ }^{26}$ Kjaer, Constitutionalism in the Global Realm.
} 
principles and normative objectives. ${ }^{27}$ Contemporary global law can therefore be understood as functional, but not as normative, equivalents to imperial and colonial law. Functionally, global law in its imperial as well as contemporary governance form can be understood as aimed at facilitating transplantations of components of meaning from one legally structured context to another and can, as such, be understood as a de-centred phenomenon manifested in inter-contextuality and inter-legality. ${ }^{28}$ In terms of the normative foundation, the essential outlook and guiding principles have, however, changed from asymmetric distinctions to a formal reliance on symmetric articulations of fundamental equality as most notably expressed in the formal adherence to global human rights. $^{29}$

The connectivity orientation is clearly observable in relation to the private law organization of global value chains serving as a central infrastructure of the global economy. ${ }^{30} \mathrm{~A}$ global value chain can be defined as a contract-based network stretching from suppliers to customers and capital owners, which, just as colonial law, is engaged in the transplantation, i.e. extraction, transmission and incorporation, of condensed components of meaning with economic value, i.e., capital, products and persons, from one legally structured societal context to another, with such transplantations being either upstream or downstream or a combination thereof, and implying

\footnotetext{
${ }^{27}$ For European nation states, see N. Elias. Über den Prozeß der Zivilisation, Band 2 (Frankfurt am Main: Suhrkamp Verlag, 1976 [1938]).

${ }^{28}$ M. Amstutz and V. Karavas, 'Weltrecht: Ein Derridasches Monster'; B. De Sousa Santos, Toward a New Legal Common Sense (Cambridge University Press, 2002).

${ }^{29}$ P.F. Kjaer, 'Constitutionalizing Connectivity: The Constitutional Grid of World Society', Journal of Law and Society, 45, S1, $114-34,2018$.

${ }^{30}$ G. Baars et al., 'The Role of Law in Global Value Chains: A Research Manifesto', (2016) 4 London Review of International Law 57.
} 
boundary crossings. The legal norms guiding, stabilizing and enabling global value chains are therefore to be thought of as connectivity norms, i.e. norms oriented towards a facilitation of material transplantations across contextual boundaries, which are intrinsically linked to issues of inter-contextuality and inter-legality.

In contrast to the common understanding of global value chains as a recent phenomenon a near to evident relation exists between colonial law and contemporary global value chain law. The postWorld War II emergence of global value chains was largely a re-invention as legally structured transplantations have been a constitutive element of commerce from day one, just as value chains with a global reach have been running since the emergence of European colonialism in the late fifteenth century. The slave trade, for example, coming out of Africa for the Arabic world as well as the Americas, also implied complex value chains and elaborated legal framings. ${ }^{31}$ Similarly to colonial law, as a collage of partly overlapping and partly contradictory legal principles and practices, global value chain law is a collage of legal, managerial and other social praxes, techniques and principles which tend to establish internal normative orders acting as third spaces between the various sites connected through value chains ${ }^{32}$ - normative orders which are

${ }^{31}$ P. Manning, 'The Slave Trade: 'The Formal Demographics of a Global System”' in J.E. Inikori and S.L. Engerman (eds.), The Atlantic Slave Trade: Effects on Economies, Societies and Peoples in Africa, the Americas, and Europe (Durham NC: Duke University Press, 1992) 117.

${ }^{32}$ L.C. Backer, 'Economic Globalization and the Rise of Efficient Systems of Global Private Lawmaking: Wal-Mart as Global Legislator', (2007) 39 University of Connecticut Law Review 1739; L.C. Backer, 'Are Supply Chains Transnational Legal Orders? What we can Learn from the Rana Plaza Factory Building Collapse', (2016) 1 UC Irvine Journal of International, Transnational and Comparative Law 11; L.C. Backer, 'Theorizing Regulatory Governance within its Ecology: The Structure of Management in an Age of Globalization', (2018) 24, 5, 607 - 30, Contemporary Politics; K.H. Eller, 'Private Governance of Global Value Chains from Within: Lessons From and For Transnational Law', (2017) 8 Transnational Legal Theory 296. 
reflected in self-descriptions and articulations of justifications for the processes they facilitate and stabilise. ${ }^{33}$ In addition, contemporary global value chain law is characterised by the same kind of mixture between public and private as colonial setups were. As argued by Martti Koskenniemi, colonialism was from the outset predominantly a private law based endeavour ${ }^{34}$ and only gradually did public law gain a larger role on the basis of an increased switch from the maintenance of trading posts to direct territorial conquest and control. Colonial law is therefore not easily categorized as either private or public law. In a similar vein, global value chain law is characterised by a structural predominance of private law while hybrid constellations have emerged with (inter-)national public law institutions ranging from the EU, OECD and the UN, e.g. the UN Global Compact, as well as nation state initiatives, and a corresponding focus on issues such as corporate social responsibility, human rights, labour and environmental regulation and anti-corruption initiatives. ${ }^{35}$

In a similar vein, the EU legal order, the most mature and manifest non-state public law legal order, grew out of the European continental empires. In spite of the resilience of 'Westphalian

\footnotetext{
${ }^{33}$ P.F. Kjaer, 'Why Justification? The Structure of Public Power in Transnational Contexts', (2017) 8 Transnational Legal Theory 8.

${ }^{34}$ M. Koskenniemi, 'Empire and International Law: The Real Spanish Contribution', (2011) 61 University of Toronto Law Journal 1.

${ }^{35}$ See for example, EU Directive on Non-financial and Diversity Information (Directive 2014/95/EU); ISO 26000 Standard on Social Responsibility; OECD Guidelines for Multinational Enterprises. See also K. Buhmann, 'Business and Human Rights: Understanding the UN Guiding Principles from the Perspective of Transnational Business Governance Interactions', (2015) 6 Transnational Legal Theory 399; S. Deva and D. Bilchitz (eds.), Human Rights Obligations of Business: Beyond the Corporate Responsibility to Respect? (Cambridge University Press, 2013).
} 
semantics', freestanding and sovereign nation states have never existed in the European context. Modern Germany and Italy emerged and operated as Prussia and Piedmont-Sardinia within the pre-existing imperial frame of the Holy Roman Empire until 1806 as well as its various succeeding formations. The same is the case with the nation states of Central and Eastern Europe. From the implosion of the Central and Eastern European empires to 1945 in the case of Western Europe and until the fall of the Soviet Union in 1991 for Eastern Europe, the totalitarian version of imperialism, transcending nation state categories furthermore maintained dominance. A development which in the interwar period was complemented with a transnational cartelisation of the economy in relation to the dominant sectors of the economy, such as aluminium, steel, coal and rubber, effectively, and in complementarity with colonialism, established a private law based transnational ordering of the global economy. ${ }^{36}$

It was first the dual and simultaneous re-constitution of Western European nation states and the establishment of a public law based transnational law-based order for Western Europe in the immediate post-World War II years which established an outright supremacy of legally constituted public power in Western Europe. All continental Western European states obtained new constitutions or substantially revised their constitutions in this period while launching far-reaching socio-economic reforms. Simultaneously, the transnational order of Western Europe was reconstructed via the allied occupation regime in Germany from 1945-55, the Marshall Plan from 1947-51, and the processes initiated with the Schuman Declaration of 1950 leading to the

\footnotetext{
${ }^{36}$ P.F. Kjaer, 'The Transnational Constitution of Europe's Social Market Economies. A Question of Constitutional Imbalances?', Journal of Common Market Studies, 57, 1, 143 - 58, 2019.
} 
establishment of the European Coal and Steel Community of 1952 and subsequently the Treaty of Rome and the European Economic Community in $1957 .{ }^{37}$

The EU legal order which grew out of these initiatives is in several aspects to be understood as post-imperial legal order. It is a legal order which runs in parallel to the legal orders of the member states. As such the EU legal order is not to be understood as representing the sum of member state legal orders but rather as an autonomous legal order running side by side with member state legal orders, with none of them factually enjoying supremacy in spite of the internal claims of both member states and the EU represented by the Court of Justice of the European Union to supremacy. ${ }^{38}$ Just like the earth and the underworld are linked by the river Styx in Greek mythology, the EU and the member state legal orders are materially interconnected through Comitology Committees and other in-between governance arrangements allowing for the transfer of legal texts, political decisions, knowledge, personnel and other components of meaning between them. As a result of this structural setup, both the EU and the member state legal orders thereby obtain spaces where they can maintain their internal conceptuality of autonomy while being structurally dependent on each other within an inter-legal arrangement. ${ }^{39}$

A second trait is that EU law, as especially embodied in the principles of the single market concerning free non-discriminatory flow of goods, capital, services and labour, is primarily structured on the basis of connectivity norms, i.e. norms aimed at enabling the separation, transmission and incorporation of components of meaning, from one legally structured context to

\footnotetext{
${ }^{37}$ Brunkhorst, Critical Theory of Legal Revolutions; J.E. Fossum and A.J. Menéndez, The Constitution's Gift: A Constitutional Theory for a Democratic European Union (Lanham MD: Rowman \& Littlefield, 2011).

${ }^{38}$ Kjaer, 'Claim-making and Parallel Universes'.

${ }^{39}$ Kjaer, Between Governing and Governance.
} 
another. As such the legal structure and principles of the EU and the effects they produce are of a fundamental different kind than those engrained in the constitutional orders of nation states. While nation states also aim to facilitate interconnectedness this is predominantly expressed through and subordinate to principles of unity aimed at establishing collectivity through coherency norms. This is particularly clear within constitutional law as, for example, expressed through reference to states or nations as indissoluble unities. ${ }^{40}$ The EU is therefore neither a functional nor a normative equivalent to its member states but a complementary structure standing in an orthogonal relationship to its members.

A third characteristic of the EU is it boundarylessness. The only material criterion for enlargement is that the applicant state is a 'European state', with no definition or delineation given in geographical, cultural or political terms. ${ }^{41}$ As the concept of Europe always have been in flux at different times in history referring to the Mediterranean basin, including North Africa and parts of contemporary Middle East; the Christian world; or the part of the world subscribing to the Western Church as well as periodically excluding or including Russia, it remains a factually springy delineation. Also due it its self-description as an 'area of freedom, security and justice' and as an 'economic area' rather than as a territorial entity the EU gains the traits of a, in principle, boundary-less entity which has no prescribed territorial limits. As such the EU is a boundary-less structure operating in the dimension of space rather than territory. ${ }^{42}$ The EU is an entity which,

\footnotetext{
${ }^{40}$ For example, the indissoluble unity of the Spanish Nation as stated in Section 2 of the Preamble of the Spanish Constitution. Available at: http://www.congreso.es/portal/page/portal/Congreso/Congreso/Hist Normas/Norm/const espa texto ingles 0.pdf. 41 https://web.archive.org/web/20060321034825/http://www.europarl.eu.int/enlargement/briefings/23a2 en.htm. (accessed 15 March 2018).

${ }^{42}$ A. Supiot, 'The Territorial Inscription of Laws', in G-P. Calliess et al. (eds.), Festschrift Teubner, 375.
} 
furthermore, has been structurally driven forward not only by the implosion of the continental empires but also by the reconfiguration of Europe's relations to the rest of the world, as the implosion of the overseas colonial empires provided functional needs for substituting colonial market access with increased European integration - a need most visible in relation to the accession of the United Kingdom to the European Community in the face of the implosion of its empire. Also in the case of the United Kingdom the idea of a sovereign nation unbound by global structures, as currently envisaged by advocates of Brexit, has never had factual reality. The United Kingdom emerged and became institutionally stabilized as a state in a process which went hand in hand with the expansion of the empire and as such the United Kingdom was always embedded in a legal structure which was larger than itself. In the moment of decolonization the imperial form of global integration was merely substituted with integration into the European construct, with this alteration however implying a switch from a reliance on the asymmetric norms of colonialism to the symmetric norms of equality formally guiding relations between EU member states. While serving as a functional equivalent to empire, emerging as a response to the implosion of both the continental and the colonial empires of Europe, the EU is formally committed to the 'respect for human dignity and human rights, freedom, democracy, equality and the rule of law', ${ }^{43}$ and this makes its normative articulations fundamentally different from those engrained in imperial law. ${ }^{44}$

As we will return to in in the following section, the emergence and evolution of the EU legal order can thus be considered part of a fundamental transformation away from the asymmetric norms characterising imperial law and towards a new foundation in symmetric norms, as most clearly visible in the turn to human rights, acting as an inherent part of contemporary global governance

\footnotetext{
${ }^{43} \mathrm{http} / / /$ europarlamentti.info/en/values-and-objectives/values/ (accessed 16 March 2018).

${ }^{44}$ Although the norms of equality were severely inflicted in the Euro-crisis and the subsequent bailouts. See J. White. ‘Authority after Emergency Rule', (2015) 78 Modern Law Review 585.
} 
law. One important difference can however be observed in this regard. While the EU is emphasizing the equality of its member states it is factually acting as suzerain, i.e. uppersovereign, in relation to its immediate neighbours. Belarus remains the only state in the region with which the EU does not have a structured legal relationship. The members of the European Economic Area (Iceland, Liechtenstein and Norway), as well as states such as Switzerland and Turkey are all subject to 'unequal treaties' factually admitting the EU as the central source of law and the Court of Justice of the European Union as the final arbiter and authority when it comes to the relations between these states and the EU. The EU is currently seeking to replicate this approach in relationship to the United Kingdom as part of the ongoing Brexit process. This is for example visible through the initial EU demand concerning indefinite extra-territorial jurisdiction for the Court of Justice of the European Union when it comes to EU citizens residing in the United Kingdom and a call for the Court to act as final authority in future legal disputes. So while one motive behind Brexit might be a longing for the asymmetric form of globality inherent to empire, the pursuit of Brexit is likely to lead to a new form of asymmetric relation between the UK and EU with the UK in the subordinate position.

4. From Asymmetric to Symmetric Inter-legality?

Contemporary global governance law from EU law to global supply chain law is like its imperial predecessors primarily oriented towards the facilitation of transplantations, i.e. the extraction, transmission and incorporation of components of meaning, from one legally structured context to another. Imperial law in both its continental and in its colonial form relied on fundamentally asymmetric relations between centre and periphery on the basis of legally entrenched normative distinctions between Christians/non-Christians, civilised/non-civilised and between upper- and 
lower-sovereigns. The issue of the EU's legal relations to its immediate neighbours apart, this is fundamentally different in contemporary global governance law which to a large extent derives its normativity from human rights.

The abounding human rights literature is essentially circling around three perspectives. First, continuity approaches emphasizing linear connections between, on the one hand, the Atlantic, i.e. American, French and Haitian, revolutions in the late eighteenth century and the abolition movement in relation to slave trade and slavery, and, on the other hand, the contemporary global human rights regime. ${ }^{45}$

Second, approaches taking a middle way between continuity and discontinuity by emphasizing the Holocaust; the UN Declaration of Human Rights of 1948 and the European Convention on Human Rights from 1953 as providing central impetus to the evolution of human rights. ${ }^{46}$ Third, discontinuity approaches, emphasising decolonization and other political developments in the 1960 s and 1970s as the central vehicles for the emergence of global human rights. ${ }^{47}$

Common to these three approaches is however a strong emphasis on the normative value of human rights and comparatively little emphasis on the actual structure, location and effects of human rights norms in world society and the differences between human rights and earlier

\footnotetext{
${ }^{45}$ S. Buck-Morss, Hegel, Haiti, and Universal History (Pittsburgh PA: University of Pittsburgh Press, 2009); L. Hunt. Inventing Human Rights: A History (New York: W.W. Norton \& Company, 2007); J.S. Martinez, The Slave Trade and the Origins of International Human Rights Law (Oxford University Press, 2014).

${ }^{46}$ P. Alston. 'Does the Past Matter? On the Origins of Human Rights', (2013) 126 Harvard Law Review 2043; S.-L. Hoffmann, 'Human Rights and History', (2016) 232 Past and Present 279.

${ }^{47}$ S. Jensen. The Making of International Human Rights: The 1960s, Decolonization, and the Reconstruction of Global Values (Cambridge University Press, 2016); S. Moyn, The Last Utopia: Human Rights in History (Cambridge MA: Harvard University Press, 2010).
} 
articulations of normativity as found in imperial law. When contextualised within the broader context of global law three core characteristics of human rights can, however, be observed which enable an understanding of them as falling within the category of global law. First, human rights are characterized by globality and boundarylessness in so far as they act as a universal public good which can be deployed and drawn upon in an infinite number of legal and social contexts and does, as such, transcend territorial boundaries.

Second, the normative foundation of human rights is bound up on a notion of fundamental equality of all humans thereby giving them an explicit symmetric foundation which differs from the asymmetric distinctions of imperial law.

Third, a drive to universalization, in the sense that institutionalized human rights settings are characterised by expansionist internal dynamics materialized in quests for 'complete inclusion', i.e. the contra-factual proposition that all of humanity - both formally and factually - should be subject to human rights protection. ${ }^{48}$

While imperial law as well as contemporary global governance law in their external effects are oriented towards the facilitation of non-legal transplantations, i.e. the extraction, transmission and incorporation of meaning components with, for example, economic, moral, political or religious value from one legally structured context to another, human rights have historically served as a vehicle for the transplantation of law itself. From a sociological jurisprudence perspective, emphasizing the actual external effect of law, human rights act as a vehicle for the self-transplantations of law, most notably, legal norms but also a broader range of legal

${ }^{48}$ K.P. Japp, 'Zur Funktion der Menschenrechte in der Weltgesellschaft', in B. Heintz and B. Leisering (eds.), Menschenrechte in der Weltgesellschaft. Deutungswandel und Wirkungsweise eines globalen Leitwerts (Frankfurt am Main: Campus Verlag, 2015) 65. 
instruments and institutions, from one contextual setting to another. As reflected in the continuity/discontinuity debate on human rights, existing genealogies tend to be not only Western-centric but also Anglo-American centred focusing on the historical experiences of the United Kingdom and its empire and the United States and its global engagements. ${ }^{49}$ In particular in German scholarship, an understanding of global human rights as possessing the potential to establish coherence on a global scale has furthermore emerged through an understanding of global human rights as a self-constituting framework introducing a hierarchy of norms within global law settings. ${ }^{50}$ From both the Anglo-American and the German perspective human rights thereby come to appear as a singular and coherent set of norms. Such perspectives however cover up the paradox that the quest for symmetric global norms to date has been based on a profoundly asymmetric relationship with the advocates of symmetry largely being located in a part of the world enjoying an asymmetrical structural position vis-à-vis the rest of the world. The ongoing decentring of the Western-centric world is however likely to challenge the singular perspective. Rather than conceiving of global human rights as a singular set of norms it might be considered a common resource of symmetric normative articulations with a conglomerate character from where legal actors located at different sites of the local, national or transnational level of world society can derive norms enabling them to address concrete legal problems. ${ }^{51}$ The actual manifestation of human rights might therefore be relationally decided in the concrete societal and legal contexts in which they are transplanted and not least in the third spaces located in-between

\footnotetext{
${ }^{49}$ For an exception in relation to France see Grandmaison, 'The Exception and the Rule'.

${ }^{50}$ H. Brunkhorst, 'Dialectical Snares: Human Rights and Democracy in the World Society', (2009) 2 Ethics and Global Politics 219.

${ }^{51}$ A. Supiot, Homo Juridicus. Essai sur la fonction anthropologique du droit (Paris: Édition du Seuil, 2005).
} 
the multitude of community-based, state-based and transnational legal orders making up the global legal landscape.

\section{Conclusion: The Inter-legality Function of Global Law}

Global law is an inter-legal and inter-contextual phenomenon characterised by boundarylessness and universalization. While global law has undergone profound structural transformations as expressed in the transformations from imperial and colonial law to contemporary global governance law, the core functional nucleus of global law remain. Global law settings are characterised by a structural pre-eminence of connectivity norms, as opposed to coherence or possibility norms, and an external orientation towards the facilitation of transplantations, i.e. the extraction, transmission and incorporation of components of meaning, from one legally structured context to another. It is a law which constitutes a third space between sites of extraction and sites of incorporation establishing material interconnectedness while neither belonging to the extraction or the incorporation site.

Global law has undergone a profound transformation in its internal conceptuality and structural composition as part of the switch from imperial and colonial law to contemporary global governance law. This transformation is most clearly expressed in the reconstruction of connectivity norms as symmetric norms aimed at ensuring fundamental equality, as opposed to the asymmetric foundation of imperial law as expressed in imperial distinctions such as Christians/non-Christians and civilised/non-civilised and the concept of suzerain, i.e. uppersovereign. The symmetric conceptuality inherent to contemporary global governance law is most

explicitly found in the adherence to global human rights. To date, global human rights have, 
however, served as vehicles of transplantations of legal norms with a European and Western imprint to the rest of the world, thereby acting as a vehicle for the self-transplantation of law. In the post-western centric world global human rights might, however, be considered a common resource of normative articulations with a conglomerate character from where legal actors located at different sites of the local, national or transnational level of world society can derive norms enabling them to address concrete legal problems. Such a perspective is in tune with the actual function, evolution and location of global law as a decentred 'in-between worlds' phenomenon characterised by inter-contextuality and inter-legality. 